\title{
IDO1 wt Allele
}

National Cancer Institute

\section{Source}

National Cancer Institute. IDO1 wt Allele. NCI Thesaurus. Code C79780.

Human IDO1 wild-type allele is located in the vicinity of 8p11.21 and is approximately 27 $\mathrm{kb}$ in length. This allele, which encodes indoleamine 2,3-dioxygenase 1 protein, plays a role in tryptophan metabolism. Expression of the gene is associated with reduction in cellular immune responses. 